\title{
Impact of coal mine overburden leachates on pea plant growth with their quality
}

\section{S. K. GUDADHE}

Article Chronicle:

Received :

02.08.2017;

Revised :

12.11.2017;

Accepted :

22.11.2017
ABSTRACT : The study was carried out on coalmine overburden leachate's effect on pea plant growth and also investigated the quality of leachates. The pea plant growth performance was shown in coalmine overburden leachates and growth compare with standard water. The pea plant has low growth in leachates as compared with standard water and the physico-chemical parameters i.e. temperature, $\mathrm{pH}$, electrical conductivity, total organic carbon, total nitrogen and total phosphate of coal mine overburden leachates are higher than standard water and parameters are slightly higher than permissible limit.

HOW TO CITE THIS ARTICLE : Gudadhe, S.K. (2017). Impact of coal mine overburden leachates on pea plant growth with their quality. Asian J. Environ. Sci., 12(2): 93-96, DOI: 10.15740/HAS/AJES/12.2/93-96.

Key Words :

Coal mine, Overburden, Leachates, Pea plant 